\title{
The Mediating Role of Brand Engagement and Store Image on Relationship between Brand Identification and Purchase Intention: a Study of Omani Retail Market
}

Received: 24.07.2021

Available online: 28.12.2021

Dr. Zaheer Ahmed Khan*, Hyder Kamran**, Ermal Bino***

\section{Abstract}

Based on the convergence of socialidentity and theory of reasoned action (TORA), the purpose of this research is to investigate the mediating effect of brand engagement and store image on the relationship between consumer brand identification and purchase intention. The study empirically investigates a theoretical framework developed from literature evidence using partial-least squares (PLS) structural equation modeling (SEM) to test hypotheses. A structured questionnaire, measuring items on a Likert seven scale, was used to collect data from 344 participants among shoppers of famous retail chains in Muscat. The results indicated that store-brand identification (SBI) alone is a weak predictor of purchase intention (PI). The results revealed that brand engagement $(\mathrm{BE})$ and store image (SI) fully mediate the relationship between SBI and PI. Intrinsically, the study serves to enhance the insight into customers' attitudes towards private-labeled store brands with a focus on the Omani retail market. The findings contribute a valuable insight on retail marketing strategies, and an interpretation into branding literature related to retail marketing and provide an understanding of marketing strategies and guidance for retail store management in Oman both at a strategic and tactical level.

Keywords: Store Brand Identification, Customer-Brand engagement, Purchase intention, Store Image, Mediation effect, Consumer Behavior

JEL: D11, M20

\section{Introduction}

ver the last two decades, marketing research has focused more attention on the dynamics of consumer-brand relationships. Several studies have identified brand identification as an important factor in establishing a customer-brand relationship for improved brand performance. Brand identification is a positive cognitive, emotional, and behavioral activity during or related to

\footnotetext{
* Mazoon College, Oman

** University of Buraimi, Oman

${ }^{* * *}$ University of Buraimi, Oman
} 


\section{Articles}

consumer-brand interactions (De Vries \& Carlson, 2014). Originating from social identity theory, the concept of store brand identification $(\mathrm{SBI})$ is the classification of distinctive characteristics of interest and attributes that serve as a perceptual construct that identifies fit and match of brands offered (Bhattacharya et al., 1995). Brand identification reflects the buyer's connection with store image (SI). Generally, satisfaction and trust influence the purchase intention (PI) of consumers (Chiu et al., 2013). However, previous researchers have emphasized two theoretical viewpoints. The first relates to value theory which focuses on value perception (Molinillo et al., 2017) and explains how consumers remain loyal based on quality perception. The second is focused on the identification approach which considers brand identification to be a history of brand loyalty (Tuškej et al., 2013). Consumer brand identification is a behavioral aspect that explains when and how a brand is helpful to consumers in articulating brand identity. The process of identifying consumer brands has positive implications for the business. Brand identification relies on brand promotion and loyalty; Keller (2001) explained that customers identify brands with organizations. The concept of consumer-brand identification has five consequences: loyalty, promotion of the company, recruitment of new customers, resilience to information, and a claim on the company. In evolving markets like Oman, instore private-labeled branding is an emerging strategy of retail marketing. It is a fundamental characteristic of branding strategies that the development of a brand is related to brand engagement (BE), store image (SI), and consumer loyalty (Lado et al., 2017; Rather \& Sharma, 2017). In terms of brand identification, research makes no difference between developed and developing countries
The Mediating Role of Brand Engagement and Store Image on Relationship between Brand Identification and Purchase Intention: a Study of Omani Retail Market

(Odoom et al., 2017). Generally, theoretical models used in developed countries expose an inconsistency due to contextual differences with underdeveloped ones (Sheth, 2011). Most of the evidence studies have investigated brand identification and brand engagement in developed countries. Some recent studies (Burgess \& Steenkamp, 2013; Hollebeek et al., 2016; Rather \& Sharma, 2017) have recommended investigating the brand-engagement across other contexts and places. The evidence from the literature merits to explain the phenomenon using a methodological approach in the local context of Oman. Based on social identity theory and theory of reasoned action, the present research aims to explain the mediation effect of $\mathrm{BE}$ and $\mathrm{SI}$ on the relationship between store brand identification and purchase intention through a described methodology.

\section{Literature review and hypotheses}

\subsection{Consumer Brand Engagement}

Customer brand engagement is the customer's behavioral manifestations beyond the transaction. Vivek et al. (2012) have explained consumer engagement as the intensity of participation in offerings by an organization where the customer or the organization initiates. A multi-dimensional concept combining cognitive, emotional, and behavioral elements creates brand engagement. An experience creating elements such as attention, dialogue, interaction, emotions, sensorial pleasure play a role in customer brand engagement (Gambetti et al., 2012). Hollebeek et al.(2016) defined the customer-brand engagement as the customer's motivationally driven conjecture into brand interactions. Brand engagement is a two-dimensional concept; it involves 


\section{Articles}

personal interest and interest in information that is influenced by social and consumercentered factors. (Chahal et al., 2019). Consumer brand engagement is an interaction of subjective and objective engagement. The marketing literature categorizes BE into two conceptualizations. The first involves behavioral elements (Van Doorn et al., 2010) and the second involves three dimensions: behavioral, cognitive, and emotional (Dwivedi, 2015; Rather et al., 2018). Interaction with brands is driven by psychological ownership and brand suitability (Kumar \& Nayak, 2019). Brand engagement and brand identification are closely related to customer satisfaction, referrals, and word of mouth (Carvalho \& Fernandes, 2018). Kumar (2020) argues that there are different dimensions of customer brand engagement and their effects on the brand-customer relationship. In conjunction with brand engagement, satisfaction and self-expression are associated with cognitive processing that influences brand outcomes such as brand association and purchase intent (Nyadzayo et al., 2020). Machado et al. (2019) have reported a mediating role of consumerbrand engagement (CBE) and brand love (BL) on this relationship. This study proposes the following hypotheses based on the theoretical dimensions.

$\boldsymbol{H}_{1}$ : Brand engagement (BE) significantly influences purchase intention (PI).

$\boldsymbol{H}_{2}$ : Brand engagement (BE) mediates the relationship between store-brand identification (SBI) and purchase intention (PI).

\subsection{Store Brand Identification and purchase intention}

Brand identification $(\mathrm{BI})$ is a perceived state of the rationality of a consumer with a brand. Lam et al. (2013) defined consumer brand identification as "a customer's psychological state of perceiving, feeling, and valuing his or her belongingness with a brand". The concept of consumer-brand identification is an articulation of the identity under the influence of brand-self-similarity, brand distinctiveness, brand social benefits, brand warmth, and memorable brand experiences (StokburgerSauer et al., 2012). In-store branding is a strategy of success to offer a value and meet the customer's expectations benefitted through corporate branding as facilitator (Cook, 2010). Experiencing a brand through sensation, intellect, affection, and behavior influences the brand loyalty of customers (Ong et al., 2018). Retail stores sell private labels on the strength of their corporate identity and customer trust. Retailers prefer to sell private brands for a high contribution to the profit margin because these brands are not sold by other brands. Usually, such brands are attributed as cost-saving for customers, and they choose a private label for price motivation. The principal cue in the success of in-store brands is store image, corporate identity, and reputation of the retailer that reduces the purchasing risk (Kanai et al., 2017). The behavioral intention of customers is predicted by image and value perception (Jin et al., 2015) which relates to customer satisfaction. Behavioral intention is a planned behavior, and this is a substitute indicator for actual behavior.

$\boldsymbol{H}_{3}$ : Store brand identification (SBI) significantly influences brand engagement (BE).

$\boldsymbol{H}_{4}$ : Store-brand identification significantly influences purchase intention (PI).

$\boldsymbol{H}_{5}$ : Store brand identification (SBI) significantly influences store image (SI). 


\section{Articles}

\subsection{Store Image}

Store image is a multi-dimensional concept that includes key store attributes such as the quality of merchandise, the atmosphere of the store, the layout, the quality of services by store and used by the consumer in determining a store image (Diallo, 2012; Triantafillidou et al., 2017). Therefore, store image is the learned impression of retailers in the mind of consumers and is developed through the subjective and objective perceptions of customers. Store image positively and directly influences the consumer's evaluation of private brands. Store image is an antecedent of brand response of private-labeled brands (Beneke et al., 2015), which serves as an extrinsic information cue for quality of store brand and purchase intention towards in-store brands (Bao et al., 2011). Hameed (2013) has reported that store image mediates the relationship between perceived quality and customer trust. Store image has a direct and positive effect on the purchase intention (Diallo \& Siqueira Jr, 2017) of customers which represents the likelihood for future purchase of a similar brand. Besides other factors, store image is influenced by corporate reputation store image affect store loyalty. Store image has a positive and direct effect on purchase intention and consumers use store image as an extrinsic attribute (Narteh \& Braimah, 2019; Varghese, 2020; Wu et al., 2011). Basic dimensions of retail store image affect the retailer's brand equity which in turn leads to the positive attitude of consumers (Anselmsson et al., 2017; Troiville, J., Hair, J. F., \& Cliquet, 2019). Therefore, we have hypothesized the following.

$\boldsymbol{H}_{6}$ : Store image (SI) significantly influences purchase intention $(\mathrm{Pl})$.
The Mediating Role of Brand Engagement and Store Image on Relationship between Brand Identification and

Purchase Intention: a Study of Omani Retail Market

$\boldsymbol{H}_{7}:$ Store image (SI) mediates the relationship between store-brand identification (SBI) and purchase intention (PI).

\section{Theoretical background}

The conceptual framework of this research integrates the fundamental aspects of the consumer-brand relationship and their effect on the behavioral intention of consumers mediated by store image and brand engagement. The research is grounded in the convergence of social-identity theory (Tajfel \& Turner, 1985) and theory of reasoned action (TORA) that illuminates marketing theory and consumer behavior in a particular way, and leads customers to perform the actual behavior (Ajzen \& Fishbein, 1975). The social identity theory and theory of reasoned action proposes a theoretical structure of switching behavior as social mobility of customers between brands they identify under the aspirations of functional utility maximization. This theory further suggests that instituting a brand link with the consumer is workable when identity is congruent with the brand image and social identity. TORA framework is useful in evaluating the attitudes of individuals towards a target behavior and subjective norms to explore the role of extrinsic motivators that influence intentions (Yzer, 2017).

\section{Methodology}

This study is an explanatory that aims to investigate the relationship between store brand identification and purchase intention of customers under intervention of brand engagement and store image. Therefore, for a cause-and-effect study that involves hypothesis testing under a grounding theory, a quantitative method is an appropriate choice involving the collection of data from a representative sample of the target population 


\section{Articles}

(Bloomfield \& Fisher, 2019). Hence, using quantitative method a cross-sectional representation of the views on the study variables (i.e., SBI, PI, SI. CBE) is intended to generalize outcomes (Tsang, 2014) to the population. In the current study, the target population was customers retail of store chains in Oman. Selection criteria included availability and willingness to participate in survey. Therefore, convenience sampling (Etikan et al., 2016) sampling was adopted using the client database of 3 selected retail stores in Muscat city. A self-administered questionnaire (worded both in Arabic and English) was distributed through e-mail to 800 consumers in Oman. With a response rate of $43 \%, 344$ useable questionnaires were returned by participants of varied demographic characteristics (Table 1); sample size exceeded the minimum requirement (Hair Jr et al., 2021) of 200 to 500 PLS.

Table 1. Demographic profile of respondents

\begin{tabular}{llc}
\hline \multirow{2}{*}{ Gender } & \multicolumn{1}{c}{ Demographics } & No. \\
\hline \multirow{4}{*}{ Nationality } & Female & 252 \\
& Omani & 92 \\
\cline { 2 - 3 } & Other Asian & 65 \\
& European & 184 \\
& Other & 27 \\
\cline { 2 - 3 } Store Brand & Lulu Hypermarket & 68 \\
& Carrefour Hypermarket & 179 \\
& Sultan Centre & 108 \\
\hline
\end{tabular}

The instrument was developed on a seven-point Likert scale, (7=strongly agree; and $1=$ strongly disagree). Items for brand identification (Stokburger-Sauer et al., 2012) were adopted and modified. The measures in consumer brand engagement were based on the conceptualization of (Sprott et al., 2009) that includes the dimensions (i.e., enthusiasm, attention, and interaction). For store image, a measurement scale (Reardon et al., 1995) of 6 elements (i.e., merchandise quality, price, sales services, atmosphere, advertising, and convenience) was adopted for the study. The study was carried out based on variancebased SEM using PLS-SEM which is a prediction-oriented path modeling with a high level of complexity of model and procedures for reflective constructs and integrates mediation as a process, not as a step. PLSSEM is appropriate for a small sample size and non-reliance on strict assumptions compared to CB-SEM (Sarstedt et al., 2016).

\section{Measurement Model Assessment}

To test the reliability and validity of the variable measuring latent constructs with their manifest variables, convergent and discriminant validity were evaluated. The item loadings (Table 2) are above 0.708, thus provided acceptable item reliability. The composite reliability and rho_A values exceeded the recommended value of 0.70 . The average variance extracted (AVE) were above the acceptable (AVE is 0.50 or higher) level, which confirmed the convergent validity (Hair et al., 2019),

Table 2: Construct reliability and validity

\begin{tabular}{lcccccc}
\hline \multicolumn{1}{c}{ Construct } & Items & Loadings & Cronbach's Alpha & rho_A & Composite Reliability & (AVE) \\
\hline \multirow{2}{*}{$\begin{array}{l}\text { Brand Engagement } \\
\text { (BE) }\end{array}$} & be1 & 0.855 & 0.747 & 0.769 & 0.854 & 0.662 \\
& be2 & 0.752 & & & & \\
\hline \multirow{2}{*}{ Store Brand Identification } & be5 & 0.831 & & & & \\
(BI) & bi1 & 0.732 & 0.735 & 0.759 & & 0.652 \\
& bi & 0.836 & & & & \\
\hline
\end{tabular}




\begin{tabular}{lcccccc}
\hline \multicolumn{1}{c}{ Construct } & Items & Loadings & Cronbach's Alpha & rho_A & Composite Reliability & (AVE) \\
\hline Purchase Intention & pi1 & 0.849 & 0.690 & 0.699 & 0.829 & 0.619 \\
(PI) & pi2 & 0.762 & & & & \\
& pi3 & 0.745 & & & & \\
& si1 & 0.826 & 0.818 & 0.82 & 0.874 & \\
Store Image & si2 & 0.813 & & & & \\
(SI) & si3 & 0.790 & & & & \\
& si4 & 0.727 & & & & \\
& si6 & 0.648 & & & & \\
\hline
\end{tabular}

\subsection{Discriminative Validity}

The discriminant validity was assessed through the heterotrait-monotrait ratio of correlations (HTMT) measure (Hair et al., 2019; Henseler, J., Ringle, C. M., \& Sarstedt, 2015) and all the HTMT values are significantly lower than 0.850 (Franke \& Sarstedt, 2019) which supported discriminant validity.
Table 3: Discriminant Validity

\begin{tabular}{lllll}
\hline \multicolumn{5}{c}{ Heterotrait-Monotrait (HTMT)Criterion } \\
\hline & $\mathrm{BE}$ & $\mathrm{BI}$ & $\mathrm{PI}$ & $\mathrm{SI}$ \\
$\mathrm{BE}$ & & & & \\
$\mathrm{BI}$ & 0.820 & & & \\
$\mathrm{PI}$ & 0.881 & 0.767 & & \\
$\mathrm{SI}$ & 0.862 & 0.890 & 0.828 & \\
\hline
\end{tabular}

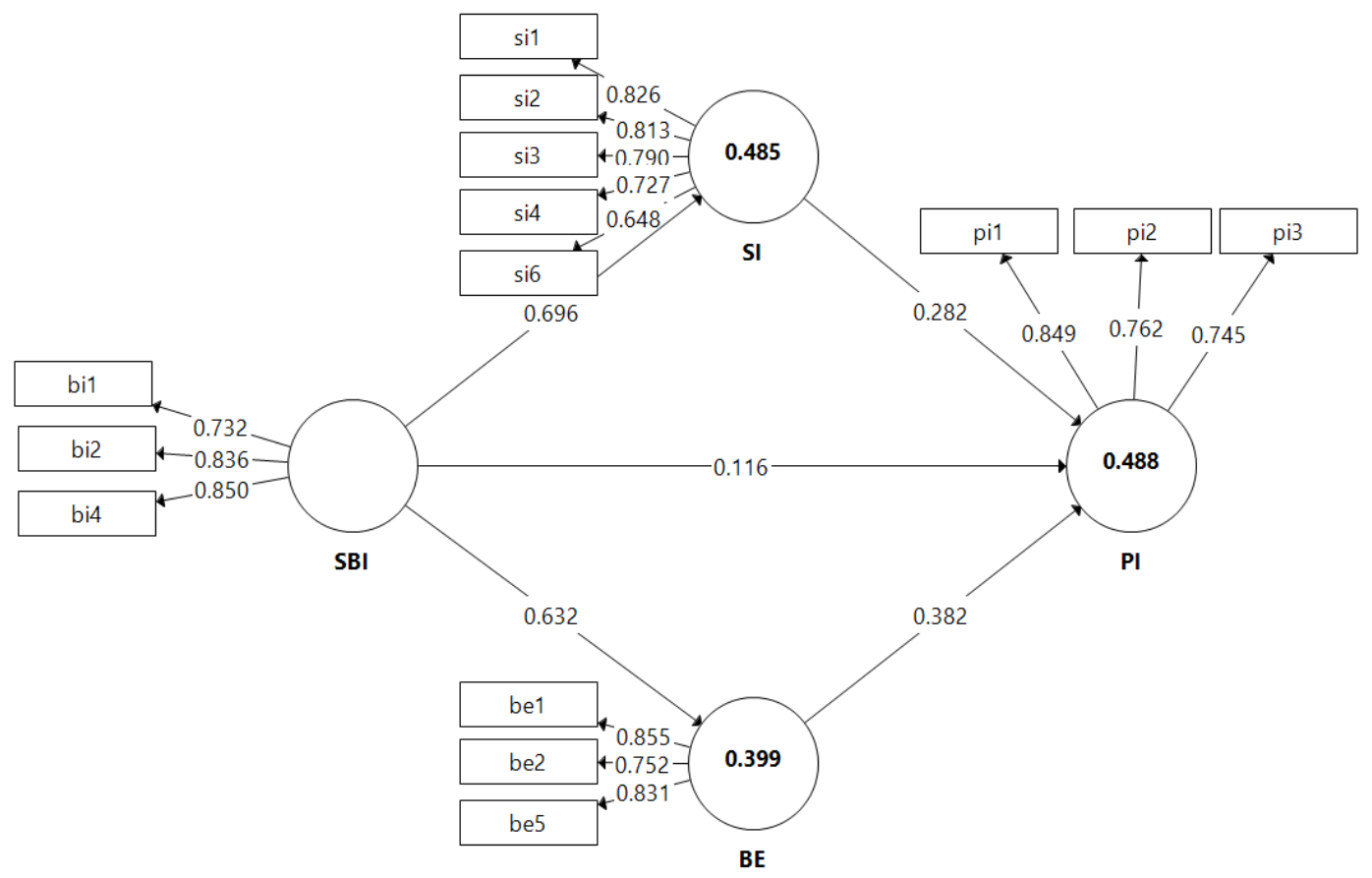

Fig. 1: Structured model 


\section{Articles}

\section{Structured Model Assessment}

To assess the hypothesized relationship between constructs of the structured model bootstrapping (5000) was used to test the statistical significance of each path (Preacher \& Hayes, 2008). The hypothesized relationships (Fig.1) were assessed by evaluating path coefficients ( $\beta$ ), $p$-value, and t-values (Hair Jr et al., 2017).
The relationship between $\mathrm{BE}$ and $\mathrm{PI}$ is significant $(H 1: \beta=0.382, t=5.840)$, the relationship between $\mathrm{SBI}$ and $\mathrm{BE}$ is significant (H3: $\beta=0.632, t=21.201$ ), the relationship between $\mathrm{SBI}$ and $\mathrm{PI}$ is not significant ( $H 4: \beta$ $=0.116, t=1,672$ ), the relationship between SBI and $\mathrm{SI}$ is significant $(H 5: \beta=0.696, t=24.949)$, the relationship between $\mathrm{SI}$ and $\mathrm{PI}$ is significant ( $H 6: \beta=0.282, t=3.871)$.

Table 4: Structure Model (direct effects)

\begin{tabular}{lcccccc}
\hline Hypothesis & Path & Std.Beta & SE & t-statistics & $\begin{array}{c}\mathbf{9 5 \%} \text { CI(BC) } \\
\text { LL, UL }\end{array}$ & Decision \\
\hline $\mathrm{H} 1$ & $\mathrm{BE} \rightarrow \mathrm{PI}$ & 0.382 & 0.065 & $5.840^{*}$ & {$[0.246,0.503]$} & Supported \\
$\mathrm{H} 3$ & $\mathrm{SBI} \rightarrow \mathrm{BE}$ & 0.632 & 0.030 & $21.201^{*}$ & {$[0.569,0.686]$} & Supported \\
$\mathrm{H} 4$ & $\mathrm{SBI} \rightarrow \mathrm{PI}$ & 0.116 & 0.069 & 1.672 & {$[-0.022,0.247]$} & Not Supported \\
$\mathrm{H} 5$ & $\mathrm{SBI} \rightarrow \mathrm{SI}$ & 0.696 & 0.028 & $24.949^{*}$ & {$[0.634,0.745]$} & Supported \\
$\mathrm{H} 6$ & $\mathrm{SI} \rightarrow \mathrm{PI}$ & 0.282 & 0.073 & $3.871^{*}$ & {$[0.137,0.424]$} & Supported \\
\hline
\end{tabular}

*Significant at $95 \% \mathrm{Cl}, \mathrm{BC}=$ Bias Corrected, UL = Upper Level, $\mathrm{LL}=$ Lower Level

BE: Brand engagement, PI: Purchase intention, SBI: Store Brand Identification, SI: Store Image

\section{Mediation Effect}

The bootstrapping analysis (Table 5) has indicated that both indirect effects $(H 2$ : $\beta=0.241, t=5.749)$ and $(H 7: \beta=0.196, t=3.775)$ are significant. Therefore, we conclude that $\mathrm{BE}$ and $\mathrm{SI}$ mediate the relationship between $\mathrm{SBI}$ and PI. The indirect effect of $\mathrm{SBI}$ in $\mathrm{CP}$ is revealed.

was not significant and all other postulated indirect effects $(B E$-> $P I, S B I->B E, S B I$-> SI, $S I->P I)$ were significant. Hence, an indirectonly full mediation (Zhao et al., 2010) of BE and $\mathrm{SI}$ on the relationship between $\mathrm{SBI}$ and $\mathrm{PI}$ irect effects

\begin{tabular}{lcccccl}
\hline Hypothesis & Path & Std.Beta & SE & t-statistics & $\begin{array}{c}\text { 95\% Cl(BC) } \\
\text { LL, UL }\end{array}$ & Decision \\
\hline $\mathrm{H} 2$ & $\mathrm{SBI} \rightarrow \mathrm{BE} \rightarrow \mathrm{PI}$ & 0.241 & 0.042 & $5.749^{*}$ & {$[0.157,0.320]$} & Supported \\
$\mathrm{H} 7$ & $\mathrm{SBI} \rightarrow \mathrm{SI} \rightarrow \mathrm{PI}$ & 0.196 & 0.052 & $3.775^{*}$ & {$[0.094,0.299]$} & Supported \\
\hline
\end{tabular}

Predictor: PI; * Significant at 95\%Cl; BC = Bias Corrected, UL = Upper Level, LL = Lower Level BE: Brand engagement, PI: Purchase intention, SBI: Store Brand Identification, SI: Store Image $95 \% \mathrm{Cl}(\mathrm{BC})$; [LL, UL] has no 0 in between which establishes a mediation (Preacher and Hayes,2008).

\subsection{Predictive Quality}

All $Q^{2}$ values greater than zero (0) for endogenous latent variables indicate the predictive relevance (Table 5) of the PLS path model for this construct (i.e., $Q^{2}>0$,
0.25 , and 0.50 represent small, medium, and large predictive relevance, respectively). Variance explained $\left(R^{2}\right)$ is good enough (i.e., 0.25, 0.50, and 0,75 indicates weak, moderate, and substantial). No collinearity 
issues were indicated as VIF values are higher than $0.02,0.15$, and 0.35 show small, below 3 (Shmueli et al., 2016; Shmueli \& Koppius, 2011). For the effect size $f^{2}$ values medium, and large effect sizes, respectively (Cohen, 1988).

Table 6: Assessment of the structural model

\begin{tabular}{lccccccc}
\hline \multirow{2}{*}{$\begin{array}{c}\text { Endogenous } \\
\text { latent constructs }\end{array}$} & R-Square & $\mathbf{Q}^{2}$ & $\mathbf{Q}^{2}$ _predict & $\begin{array}{c}\text { Construct } \\
\text { Relationship }\end{array}$ & VIF & \multicolumn{2}{c}{ Effect size } \\
\cline { 6 - 8 } & & & & $\mathrm{BE} \rightarrow \mathrm{PI}$ & 2.069 & 0.138 & Small \\
$\mathrm{PI}$ & 0.488 & 0.291 & 0.302 & $\mathrm{SBI} \rightarrow \mathrm{Pl}$ & 2.127 & 0.012 & Small \\
& & & & $\mathrm{SI} \rightarrow \mathrm{PI}$ & 2.414 & 0.064 & Small \\
\hline $\mathrm{BE}$ & 0.399 & 0.257 & 0.393 & $\mathrm{SBI} \rightarrow \mathrm{BE}$ & 1.000 & 0.664 & Large \\
\hline $\mathrm{SI}$ & 0.485 & 0.274 & 0.479 & $\mathrm{SBI} \rightarrow \mathrm{SI}$ & 1.000 & 0.942 & Large \\
\hline
\end{tabular}

Prediction errors were symmetrically $\mid$ of $Q^{2}$ _predict $>0$ and the majority of RMSE distributed therefore a comparison of RMSE values with the naïve LM benchmark indicated the predictive summary. All values in LM are greater than RSME in PLS-SEM (Shmueli et al., 2019) indicated a moderate predictive power.

Table 7: PLS predict assessment of manifest variables.

\begin{tabular}{|c|c|c|c|c|}
\hline \multicolumn{3}{|c|}{ PLS_SEM } & \multirow{2}{*}{$\begin{array}{c}\text { LM } \\
\text { RMSE }\end{array}$} & \multirow{2}{*}{$\begin{array}{l}\text { (PLS-SEM) } \\
\text { (LM RMSE) }\end{array}$} \\
\hline Items & RMSE & $Q^{2} \_$predict & & \\
\hline be1 & 1.174 & 0.290 & 1.164 & 0.010 \\
\hline be2 & 1.221 & 0.162 & 1.224 & -0.003 \\
\hline be 5 & 1.06 & 0.320 & 1.061 & -0.001 \\
\hline pi3 & 1.296 & 0.168 & 1.302 & -0.006 \\
\hline pi1 & 1.276 & 0.171 & 1.269 & 0.007 \\
\hline pi2 & 1.322 & 0.223 & 1.305 & 0.017 \\
\hline si2 & 1.616 & 0.236 & 1.619 & -0.003 \\
\hline si1 & 1.312 & 0.286 & 1.316 & -0.004 \\
\hline si6 & 1.210 & 0.318 & 1.201 & 0.009 \\
\hline si3 & 1.628 & 0.245 & 1.635 & -0.007 \\
\hline si4 & 1.328 & 0.277 & 1.329 & -0.001 \\
\hline
\end{tabular}

\section{Discussion}

The main objective of the current study was to examine the type of relationship that exists between store brand identification and the purchase intention of consumers. This research tried to examine the mediating role of brand engagement $(\mathrm{BI})$ and store image (SI) on the relationship between store brand identification $(\mathrm{SBI})$ and purchase intention (PI). The relationship between $\mathrm{SBI}$ and $\mathrm{PI}$ was positive, but insignificant, so it did not support hypothesis 1 . Apparently, this appears to contradict the conceptual clarifications provided in the literature; this establishes that $\mathrm{SBI}$ alone is a weak predictor of $\mathrm{PI}$. One of the reasons for the variation with the 


\section{Articles}

theoretical dimensions might be perceptual and behavioral factors that affect the intent of consumers to buy private labels (Beneke et al., 2013; Mostafa \& Elseidi, 2018). The results of the study indicated that brand engagement mediates the relationship between store brand identification and purchase intention. Similarly, store image mediates the relationship between store brand identification and purchase intention.

In explaining the role of store image on purchase intention the outcomes are consistent with the previous studies (Jin et al., 2015; Wu et al., 2011). Moreover, the outcomes are consistent with previous studies and explain brand engagement as significant. Furthermore, the outcomes are consistent with previous studies (Pansari \& Kumar, 2017; Rather et al., 2018) and explain brand engagement as a significant driver of the behavioral intention of customers; the role of store image (Alamsyah et al., 2017; Diallo, 2012) as an important cue of intrinsic information, subjective and objective perception.

The research has successfully elaborated on the relationship between store brand identification and purchase intention under the mediating influence of brand engagement and store image as postulated in the theoretical framework and research design of the current study. This study has clarified brand engagement and store image as a behavioral influencer of consumer intention in relationship with store brand identification. The findings of the study contribute to the existing literature within the context of the Omani retail market. The outcomes of the study provided a clear understanding of brand engagement, store image, and purchase intention in the case of in-store brand offering marketing strategies of retailers in Oman. Therefore, the results clarify the marketing strategy for in-store brands by confirming with two mediators (BE) and (SI) following the postulated framework. On the theoretical level, the findings of this study extend the explanation of SBI and its effects on $\mathrm{Pl}$ under the influence of the $\mathrm{BE}$ and $\mathrm{SI}$ as a step forward in directing theories relating to $\mathrm{BE}$ effects and SI. The current study integrated the idea of SBI with $\mathrm{BE}$ and $\mathrm{SI}$ and combined it with the effects of consumer's behavioral outcomes. The empirical investigation carried out in this study is a contribution to the existing literature as a valuable insight on retail marketing strategies in a country like Oman where in-store branding is a newly emerging market concept.

\section{Theoretical implications}

The understanding of the mediation effect of $\mathrm{BE}$ and $\mathrm{SI}$ revealed by this study provides a valuable interpretation of the retail marketing brand literature. Importantly, this study extends previous work on in-store brands, BE, and SI by providing empirical evidence on in-house branding strategies of retail marketing. The study presents a framework for integrating the image, identity, and communications of a company and makes a significant contribution to theories and practices of brand identification. Furthermore, this study established links between store brand identification, store image, and purchase intentions. Therefore, this study adds an insight into branding literature and guides retail marketing managers to understand the behavioral influencers of customer intent in relationship with store brand identification.

\section{Practical implications}

In terms of practical implications, we see some useful outcomes. The study provided an insight into marketing strategies for retail stores in Oman both at the strategic and 


\section{Articles}

tactical level. Results of the current study confirmed the mediating influences of BE and $\mathrm{SI}$ on the relationship between $\mathrm{SBI}$ and $\mathrm{PI}$ and provided a few practical implications for managers in retail management of store chains in Oman. The outcomes urge marketers in the retail segment in Oman to build a high level of brand identification among customers to support the ability to forge a long-term relationship.

Convincingly, research suggests that retail managers should engage customers with store image as learned impression and BE through cognitive processing, affection, and activation. The full mediating effect of BE and SI suggests that a positive BE and SI would increase the customer's engagement within the brand community, and consequently enable retail brands to enhance the customer intention to forward them to in-store brands. Moreover, this will aid retail store managers and business policymakers to increase business performance through increased customer engagement and trust.

\section{Limitations and Avenues for Future Research}

The sample characteristics limit the findings from being generalized to all types of brands under the product classification such as luxury goods and innovative products. One of the limitations of generalization is that data were gathered from a specific geographical area in Oman. Second, data were collected via convenience sampling without stratification of the diverse landscape of customers based in Oman. Therefore, future research in this area is recommended to propose a research model that takes into account the cultural diversity of the target participants and also the classification of products. Future studies may test the relationships between in-store brand
The Mediating Role of Brand Engagement and Store Image on Relationship between Brand Identification and Purchase Intention: a Study of Omani Retail Market

identification and purchase intention including other influencing factors such as perceptual and behavioral factors, brand experience, and media influences in branding through retail marketing.

\section{References}

Ajzen, I., \& Fishbein, M. (1975). A Bayesian analysis of attribution processes. Psychological Bulletin, 82(2), 261.

Alamsyah, D. P., Trijumansyah, A., \& Hariyanto, O. I. B. (2017). Mediating of store image on customer trust for organic vegetables. Mimbar: Journal Sosial Dan Pembangunan, 33(1), 132-141.

Anselmsson, J., Burt, S., \& Tunca, B. (2017). An integrated retailer image and brand equity framework: Re-examining, extending, and restructuring retailer brand equity. Journal of Retailing and Consumer Services, 38, 194203.

Bao, Y., Bao, Y., \& Sheng, S. (2011). Motivating purchase of private brands: Effects of store image, product signatureness, and quality variation. Journal of Business Research, 64(2), 220-226.

Beneke, J., Brito, A., \& Garvey, K.-A. (2015). Propensity to buy private label merchandise. International Journal of Retail \& Distribution Management.

Beneke, J., Flynn, R., Greig, T., \& Mukaiwa, M. (2013). The influence of perceived product quality, relative price and risk on customer value and willingness to buy: a study of private label merchandise. Journal of Product \& Brand Management.

Bhattacharya, C. B., Rao, H., \& Glynn, M. A. (1995). Understanding the bond of identification: An investigation of its correlates among art museum members. Journal of Marketing, 59(4), 46-57.

Bloomfield, J., \& Fisher, M. J. (2019). Quantitative research design. Journal of the 


\section{Articles}

Australasian Rehabilitation Nurses Association, 22(2), 27-30.

Burgess, S. M., \& Steenkamp, J.-B. E. M. (2013). Introduction to the special issue on marketing in emerging markets. International Journal of Research in Marketing, 30(1), 1-3.

Chahal, H., Wirtz, J., \& Verma, A. (2019). Social media brand engagement: dimensions, drivers and consequences. Journal of Consumer Marketing, 37(2), 191-204.

Chiu, C.-M., Fang, Y.-H., Cheng, H.-L., \& Yen, C. (2013). On online repurchase intentions: Antecedents and the moderating role of switching cost. Human Systems Management, 32(4), 283-296.

Cohen, J. (1988). The effect size. Statistical Power Analysis for the Behavioral Sciences, 77-83.

Cook, S. (2010). Customer care excellence: How to create an effective customer focus. Kogan page publishers.

De Vries, N. J., \& Carlson, J. (2014). Examining the drivers and brand performance implications of customer engagement with brands in the social media environment. Journal of Brand Management, 21(6), 495-515.

Diallo, M. F. (2012). Effects of store image and store brand price-image on store brand purchase intention: Application to an emerging market. Journal of Retailing and Consumer Services, 19(3), 360-367.

Diallo, M. F., \& Siqueira Jr, J. R. (2017). How previous positive experiences with store brands affect purchase intention in emerging countries. International Marketing Review.

Dwivedi, A. (2015). A higher-order model of consumer brand engagement and its impact on loyalty intentions. Journal of Retailing and Consumer Services, 24, 100-109.

Etikan, I., Musa, S. A., \& Alkassim, R. S. (2016). Comparison of convenience sampling and purposive sampling. American Journal of Theoretical and Applied Statistics, 5(1), 1-4.
Franke, G., \& Sarstedt, M. (2019). Heuristics versus statistics in discriminant validity testing: a comparison of four procedures. Internet Research.

Gambetti, R. C., Graffigna, G., \& Biraghi, S. (2012). The grounded theory approach to consumer-brand engagement: The practitioner's standpoint. International Journal of Market Research, 54(5), 659-687.

Hair, J. F., Risher, J. J., Sarstedt, M., \& Ringle, C. M. (2019). When to use and how to report the results of PLS-SEM. European Business Review.

Hair Jr, J. F., Hult, G. T. M., Ringle, C. M., \& Sarstedt, M. (2021). A primer on partial least squares structural equation modeling (PLSSEM). Sage publications.

Hair Jr, J. F., Sarstedt, M., Ringle, C. M., \& Gudergan, S. P. (2017). Advanced issues in partial least squares structural equation modeling. saGe publications.

Hameed, F. (2013). The effect of advertising spending on brand loyalty mediated by store image, perceived quality and customer satisfaction: A case of hypermarkets. Asian Journal of Business Management, 5(1), 181192.

Henseler, J., Ringle, C. M., \& Sarstedt, M. (2015). A new criterion for assessing discriminant validity in variance-based structural equation modeling. Journal of the Academy of Marketing Science, 43(1), 115135.

Hollebeek, L. D., Conduit, J., \& Brodie, R. J. (2016). Strategic drivers, anticipated and unanticipated outcomes of customer engagement. Taylor \& Francis.

Jin, N., Lee, S., \& Lee, H. (2015). The effect of experience quality on perceived value, satisfaction, image and behavioral intention of water park patrons: New versus repeat visitors. International Journal of Tourism Research, 17(1), 82-95. 


\section{Articles}

Kanai, M., Chien, S.-Y., \& Takemura, M. (2017). the effectS of coNSUMer perceptloN oN Store IMage aND prIVate laBel: coMparatIVe StUDy BetWeeN talWaN aND JapaN. International Journal of Multidisciplinarity in Business and Scienc, 3(3), 68-75.

Keller, K. L. (2001). Building customer-based brand equity: A blueprint for creating strong brands. Marketing Science Institute Cambridge, MA.

Kumar, J., \& Nayak, J. K. (2019). Consumer psychological motivations to customer brand engagement: a case of brand community. Journal of Consumer Marketing.

Lado, M., Alonso, P., Bhatti, M. A., Alshagawi, M., Juhari, A. S., Hair Jr, J. F., Sarstedt, M., Ringle, C. M., Gudergan, S. P., Shmueli, G., Sarstedt, M., Hair, J. F., Cheah, J.-H., Ting, H., Vaithilingam, S., Ringle, C. M., Nitzl, C., Roldan, J. L., Cepeda, G., ... Hayes, A. F. (2017). A new criterion for assessing discriminant validity in variance-based structural equation modeling. Journal of Retailing and Consumer Services, 43(1), 73-84.

Lam, S. K., Ahearne, M., Mullins, R., Hayati, B., \& Schillewaert, N. (2013). Exploring the dynamics of antecedents to consumer-brand identification with a new brand. Journal of the Academy of Marketing Science, 41(2), 234252.

Machado, J. C., Vacas-de-Carvalho, L., Azar, S. L., André, A. R., \& dos Santos, B. P. (2019). Brand gender and consumer-based brand equity on Facebook: The mediating role of consumer-brand engagement and brand love. Journal of Business Research, 96, 376-385.

Molinillo, S., Japutra, A., Nguyen, B., \& Chen, C.-H. S. (2017). Responsible brands vs active brands? An examination of brand personality on brand awareness, brand trust, and brand loyalty. Marketing Intelligence \& Planning.

Mostafa, R. H. A., \& Elseidi, R. I. (2018). Factors affecting consumers' willingness to
The Mediating Role of Brand Engagement and Store Image on Relationship between Brand Identification and Purchase Intention: a Study of Omani Retail Market

buy private label brands (PLBs). Spanish Journal of Marketing-ESIC.

Narteh, B., \& Braimah, M. (2019). Corporate reputation and retail bank selection: the moderating role of brand image. International Journal of Retail \& Distribution Management.

Nyadzayo, M. W., Leckie, C., \& Johnson, L. W. (2020). The impact of relational drivers on customer brand engagement and brand outcomes. Journal of Brand Management, 27(5), 561-578.

Odoom, R., Boateng, H., \& Asante, B. O. (2017). An empirical investigation of perceived relational benefits and brand engagement in restaurant services. International Journal of Contemporary Hospitality Management.

Ong, C. H., Lee, H. W., \& Ramayah, T. (2018). Impact of brand experience on loyalty. Journal of Hospitality Marketing \& Management, 27(7), 755-774.

Pansari, A., \& Kumar, V. (2017). Customer engagement: the construct, antecedents, and consequences. Journal of the Academy of Marketing Science, 45(3), 294-311.

Preacher, K. J., \& Hayes, A. F. (2008). Asymptotic and resampling strategies for assessing and comparing indirect effects in multiple mediator models. Behavior Research Methods, 40(3), 879-891.

Rather, R. A., \& Sharma, J. (2017). Customer engagement for evaluating customer relationships in hotel industry. European Journal of Tourism, Hospitality and Recreation, 8(1), 1-13.

Rather, R. A., Tehseen, S., \& Parrey, S. H. (2018). Promoting customer brand engagement and brand loyalty through customer brand identification and value congruity. Spanish Journal of Marketing-ESIC.

Reardon, J., Mikller, C. E., \& Coe, B. (1995). Applied scale development: measurement of store image. Journal of Applied Business Research (JABR), 11(4), 85-93. 


\section{Articles}

Sarstedt, M., Hair, J. F., Ringle, C. M., Thiele, K. O., \& Gudergan, S. P. (2016). Estimation issues with PLS and CBSEM: Where the bias lies! Journal of Business Research, 69(10), 3998-4010.

Sheth, J. N. (2011). Impact of emerging markets on marketing: Rethinking existing perspectives and practices. Journal of Marketing, 75(4), 166-182.

Shmueli, G., \& Koppius, O. R. (2011). Predictive analytics in information systems research. MIS Quarterly, 553-572.

Shmueli, G., Ray, S., Estrada, J. M. V., \& Chatla, S. B. (2016). The elephant in the room: Predictive performance of PLS models. Journal of Business Research, 69(10), 45524564.

Shmueli, G., Sarstedt, M., Hair, J. F., Cheah, J.-H., Ting, H., Vaithilingam, S., \& Ringle, C. M. (2019). Predictive model assessment in PLSSEM: guidelines for using PLSpredict. European Journal of Marketing.

Sprott, D., Czellar, S., \& Spangenberg, E. (2009). The importance of a general measure of brand engagement on market behavior: Development and validation of a scale. Journal of Marketing Research, 46(1), 92-104.

Stokburger-Sauer, N., Ratneshwar, S., \& Sen, S. (2012). Drivers of consumer-brand identification. International Journal of Research in Marketing, 29(4), 406-418.

Tajfel, H., \& Turner, J. (1985). The social identity of intergroup behavior,[in:] Worchel S. Psychology and Intergroup Relations. NelsonHall, Chicago.

Triantafillidou, A., Siomkos, G., \& Papafilippaki, E. (2017). The effects of retail store characteristics on in-store leisure shopping experience. International Journal of Retail \& Distribution Management.
Troiville, J., Hair, J. F., \& Cliquet, G. (2019). (2019). Definition, conceptualization and measurement of consumer-based retailer brand equity. Journal of Retailing and Consumer Services, 50, 73-84.

Tsang, E. W. K. (2014). Generalizing from research findings: The merits of case studies. International Journal of Management Reviews, 16(4), 369-383.

Tuškej, U., Golob, U., \& Podnar, K. (2013). The role of consumer-brand identification in building brand relationships. Journal of Business Research, 66(1), 53-59.

Van Doorn, J., Lemon, K. N., Mittal, V., Nass, S., Pick, D., Pirner, P., \& Verhoef, P. C. (2010). Customer engagement behavior: Theoretical foundations and research directions. Journal of Service Research, 13(3), 253-266.

Varghese, N. (2020). EFFECT OFF EXTRINSIC CUES ON PERCEPTION OF PRIVATE LABEL QUALITY. THE MODERATING ROLE OF STORE IMAGE. PalArch's Journal of Archaeology of Egypt/Egyptology, 17(6), 2256-2265.

Vivek, S. D., Beatty, S. E., \& Morgan, R. M. (2012). Customer engagement: Exploring customer relationships beyond purchase. Journal of Marketing Theory and Practice, 20(2), 122-146.

Wu, P. C. S., Yeh, G. Y.-Y., \& Hsiao, C.-R. (2011). The effect of store image and service quality on brand image and purchase intention for private label brands. Australasian Marketing Journal (AMJ), 19(1), 30-39.

Yzer, M. (2017). Theory of reasoned action and theory of planned behavior. The International Encyclopedia of Media Effects, $1-7$.

Zhao, X., Lynch Jr, J. G., \& Chen, Q. (2010). Reconsidering Baron and Kenny: Myths and truths about mediation analysis. Journal of Consumer Research, 37(2), 197-206. 